\title{
Toxicity of organic supplies for the egg parasitoid Telenomus podisi
}

\author{
Toxicidade de insumos orgânicos ao parasitoide de ovos Telenomus podisi
}

\author{
Débora Mello da Silva ${ }^{\mathrm{I}}$ Adeney de Freitas Bueno ${ }^{\mathrm{II}}$
}

\section{ABSTRACT}

Toxicity (dosage per hectare) of: 1) Baculovirus anticarsia $140 \times 10^{9} \mathrm{cpi}$; 2) Bacillus thuringiensis $16.8 \mathrm{~g} ; 3$ ) Azadirachtin-A, azadirachtin-B, nimbina and salamina 9.6 ppm; 4) Rotenoids 4 liters; 5) Nitrogen 1.3\%, phosphorus $3.0 \%$ and total organic carbon $8.0 \% 3$ liters; 6) Sodium silicate 2\% 4 liters; 7) Copper 7\% + calcium 3.3\% 1.8 liters; 8) Sulfur 20\% + quicklime $10 \% 1.8$ liters; 9) Chlorpyrifos 384g; 10) Distilled $\mathrm{H}_{2} \mathrm{O}$ (control) were evaluated for pupae and adults of Telenomus podisi. Treatments from 1 to 8 were in general harmless (class 1) to both pupae and adults of T. podisi. Among them, only treatment 5 and 7 presented slightly toxic to the parasitoid with a reduction in parasitism 5 days after $F_{1}$ parasitoid emergence. Differently, the chlorpyrifos was classified as slightly harmful (class 2) or moderately harmful (class 3). Therefore, the use of the tested organic agricultural supplies in the production of organic soybean is viable, without impairing the natural biological control allowed by this egg parasitoid. Chlorpyrifos use, on the other hand, is not allowed in organic soybean, but even on convention crop production, could whenever possible, be replaced by other products more compatible with T. podisi preservation.

Key words: IOBC, biological control, organic soybean, selectivity.

\section{RESUMO}

A toxicidade (dosagem por hectare) de: 1 ) Baculovírus anticarsia $140 \times 10^{9} \mathrm{cpi}$; 2) Bacillus thuringiensis $16,8 g$; 3) Azadirachtin- $A$, azadirachtin- $B$, nimbina e salamina 9,6ppm; 4) Rotenoides 4\% 4 litros; 5) Nitrogênio 1,3\%, fósforo 3,0\% e carbono orgânico total 8,0\% 3 litros; 6) Silicato de Sódio $2 \% 4$ litros; 7) Cobre 7\% + Cálcio 3,3\% 1,8 litros; 8) Enxofre 20\%, cal virgem 10\% 1,8 litros; 9) Clorpirifós 384g; 10) Água destilada (controle) foi avaliada para pupas e adultos de Telenomus podisi. Os tratamentos do 1 ao 8 foram, em geral, inócuos (classe 1) para pupas e adultos de T. podisi. Entre eles, apenas os tratamentos 5 e 7 apresentaram toxicidade sobre o parasitoide, reduzindo o parasitismo 5 dias após a emergência da geração
F1. Diferentemente, clorpirifós foi classificado como levemente nocivo (classe 2) e moderadamente nocivo (classe 3). Portanto, o uso dos insumos orgânicos avaliados é viável na produção da soja orgânica sem prejudicar o controle biológico natural deste parasitoide de ovos. O clorpirifós, entretanto, não é permitido na agricultura orgânica. Mesmo na agricultura convencional, sempre que possível, seu uso pode ser evitado, substituindo-o por outros produtos mais compatíveis com a preservação de T. podisi.

Palavras-chave: IOBC, controle biológico, soja orgânica, seletividade.

\section{INTRODUCTION}

The continuous and excessive use of chemicals in agriculture has risen great concern with the environment not only because of the high consumption of energy but also due to contamination of food chains and water worldwide (LAIRON, 2010). Therefore, in recent decades, the production and consumption of organic products has expanded (WILLER \& KILCHER, 2009). Organic soybeans have historically been highly lucrative compared to other major field crops (McBRIDE \& GREENE, 2009). However, this profitability could be further increased if problems with pests were mitigated (OERKE, 2006).

To control pests, organic soybean production systems rely exclusively on environmentally benign cultural practices, such as biological control and the non-use of synthetic chemicals (McBRIDE \& GREENE, 2009). Of the available biological-control tools T. podisi has been proven to be very important due

\footnotetext{
ICentro de Ciências Agrárias (CCA), Universidade Estadual de Londrina (UEL), Londrina, PR, Brasil.

IIEmbrapa Soja, CP 231, 86001-970, Londrina, PR, Brasil. E-mail: adeney.bueno@embrapa.br. *Autor para correspondência. Received 05.14.13 Approved 08.10.13 Returned by the author 11.07.13 CR-2013-0668.R1
} 
to its effectiveness in classical and inoculative biological control, controlling the Neotropical brown stink bug, Euschistus heros (Hemiptera: Pentatomidae), the most abundant species of the stink-bug complex that attacks soybeans in South America and other regions of the world (PANIZZI \& OLIVEIRA, 1998). Despite this importance, the use of approved insecticides of biological and mineral origin, or other organic supplies authorized for use in organic farming, is still necessary in this system (ZEHNDER et al., 2007). Therefore, this study was carried out to evaluate the toxicity of some selected different organic supplies (insecticides, fungicides and fertilizers) to T. podisi pupae emergence and adult parasitism capacity in order to better understand their compatibility.

\section{MATERIAL AND METHODS}

The experiments were carried out under controlled environmental conditions $\left[\left(25 \pm 1^{\circ} \mathrm{C}\right.\right.$;
$70 \pm 10 \%$ relative humidity; and 14/10h (L/D) photoperiod] in a fully randomized experimental design with 10 treatments (Table 1) and five replications, according to standardized protocols proposed by the International Organization of Biological Control (IOBC) (HASSAN, 1992) adapted for T. podisi parasitizing $\boldsymbol{E}$. heros eggs.

Pupae trial: Cardboard squares (around $1 \mathrm{~cm}^{2}$ ) with approximately $50 \boldsymbol{E}$. heros eggs each were offered for $24 \mathrm{~h}$ to freshly emerged T. podisi females. These cards were then transferred into vials and kept from 216 to $228 \mathrm{~h}$ to obtain T. podisi pupae (FOERSTER et al., 2004) which were then sprayed with the treatments with a Potter Tower regulated to a pressure of $1.5 \mathrm{Kgf} \mathrm{cm}^{-2}$ ensuring a deposit of $1.25 \pm 0.25 \mathrm{mg} \mathrm{cm}^{-2}$ similar to procedures adopted by CARMO et al. (2010). After being sprayed, T. podisi pupae were allowed to dry for $2 \mathrm{~h}$ and then placed inside cages (HASSAN, 1992). Twenty-four hours

Table 1 - Organic supplies tested against pupae and adults of the egg parasitoid Telenomus podisi.

\begin{tabular}{|c|c|c|c|c|}
\hline Product & Formulation & Provider/manufacturer & $\begin{array}{c}\text { Dosage } \\
\text { Product/180 } 1 \\
\mathrm{H}_{2} \mathrm{O}\end{array}$ & a.i. $\mathrm{cm}^{-2 * *}$ \\
\hline 1) Baculovirus $\mathrm{AEE}^{\circledR}$ & Baculovirus anticarsia $7 \times 10^{9}$ cpi.g $\mathrm{g}^{-1}$ & $\begin{array}{l}\text { Embrapa Employees Association } \\
\text { AEE/CNPSoja }\end{array}$ & $20 \mathrm{~g}$ & $9.7 \times 10^{2} \mathrm{cpi}$ \\
\hline 2) Dipel $^{\circledR}$ & Bacillus thuringiensis 33.6 g. $1^{-1}$ & $\begin{array}{l}\text { Sumitomo Chemical of Brazil } \\
\text { Representatives Ltd }\end{array}$ & 0.51 & $1.17 \times 10^{-4} \mathrm{mg}$ \\
\hline 3) Neemseto ${ }^{\circledR}$ & $\begin{array}{l}\text { Neem oil (Azadirachtin-A, Azadirachtin-B, } \\
\text { Nimbina and Salamina } 2.389 \mathrm{ppm}^{-1} \mathrm{I}^{-1} \text { ) }\end{array}$ & Cruangi Neem of Brazil Ltd & 4.01 & $6.6 \times 10^{-8} \mathrm{ppm}$ \\
\hline 4) $\operatorname{Arrast}^{\circledR}$ & Deguelia utilis extract (Rotenoids 4\%) & $\begin{array}{l}\text { Humânita Chemical and } \\
\text { Pharmaceutical S.A. }\end{array}$ & 4.01 & $2.8 \times 10^{-8} 1$ \\
\hline 5) Fish-Fertil Indure ${ }^{\circledR}$ & $\begin{array}{l}\text { Derivatives from crustaceans shells } \\
\text { (nitrogen } 1.3 \% \text {, phosphorus } 3.0 \% \text { and total } \\
\text { organic carbon } 8.0 \% \text { ) }\end{array}$ & $\begin{array}{l}\text { Fish Industries and Commerce of } \\
\text { Fertilizers Ltd }\end{array}$ & 3.01 & $2.1 \times 10^{-8} 1$ \\
\hline 6) $\mathrm{Na}$ silicate & Sodium silicate $2 \%$ dissolved in $\mathrm{H}_{2} \mathrm{O}$ & $*$ & 4.01 & $2.8 \times 10^{-8} 1$ \\
\hline 7) Borda-Ferti pH7 ${ }^{\circledR}$ & Copper $7 \%+$ Calcium $3.3 \%$ & $\begin{array}{l}\text { Planalquímica of } \quad \text { Brazil } \\
\text { Chemical Industry Ltd }\end{array}$ & 1.81 & $1.25 \times 10^{-8} 1$ \\
\hline 8) Lime-sulfur mixture & sulfur $20 \%+$ quicklime $10 \%$ (Polito, 2000) & $*$ & 1.81 & $1.25 \times 10^{-8} 1$ \\
\hline 9) Lorsban $480 \mathrm{CE}^{\circledR}$ & chlorpyrifos $480 \mathrm{~g} .1^{-1}$ & $\begin{array}{l}\text { Dow AgroSciences Industrial } \\
\text { Ltd }\end{array}$ & 0.81 & $2.6 \times 10^{-6} \mathrm{~g}$ \\
\hline 10) Control & Distilled $\mathrm{H}_{2} \mathrm{O}$ & - & - & - \\
\hline
\end{tabular}

*Mixture prepared at Embrapa Soybean to be used in the experiment; **Active ingredient per sprayed $\operatorname{area}\left(\mathrm{cm}^{2}\right)$. 
after the parasitoids emergence, numbered cards containing 50 E. heros eggs and honey droplets were inserted for parasitism until the trial end. Since pesticides might impair parasitoid lifetime, it is important to evaluate more than one day after the parasitism start. Therefore, a second card was placed in each cage at the fifth day of the experiment (HASSAN, 1992). One day after the insertion of the second card, trial was ended and $\boldsymbol{E}$. heros eggs transferred to closed vials until T. podisi emergence and parasitism evaluation. Also, the emergence of the T. podisi pupae was recorded.

Adult trial: 50 eggs of $\boldsymbol{E}$. heros parasitized by $\mathbf{T}$. podisi were placed in small glass vials $(12 \mathrm{~cm}$ long and $22 \mathrm{~mm}$ in diameter), each containing a droplet of honey on its inner wall. The glass vials were then sealed and maintained under controlled environmental conditions $\left[25 \pm 1{ }^{\circ} \mathrm{C} ; 70 \pm 10 \% \quad \mathrm{RH} ;\right.$ and $14 / 10 \mathrm{~h}$ (L/D) photoperiod], until the parasitoid emergence. After parasitoid emergence (adults up to $24 \mathrm{~h}$-old), glass plates $(13 \mathrm{~cm} \times 13 \mathrm{~cm})$ were sprayed with each treatment or with distilled water (control) as previously described for pupae. The vials containing the parasitoids were then connected to the cages, exposing the adult parasitoids to the dry residues on the glass plates. Twenty-four hours after the parasitoids were released into the cages, numbered cards containing host egg masses (50 E. heros eggs) and honey droplets were inserted until the trial end (6 days later). A second card was placed in each cage at the fifth day of the experiment. Similarly to pupae trial, one day after the insertion of the second card, trial was ended and $\boldsymbol{E}$. heros eggs transferred to closed vials until T. podisi emergence and parasitism evaluation.

Evaluations and analyses: Parasitism $(\%)$ and parasitoid emergence (\%) were evaluated. The data were tested for normality (SHAPIRO \& WILK, 1965) and homogeneity of variance (BURR $\&$ FOSTER, 1972) of treatments, and if necessary were transformed into $\arcsin \sqrt{X / 100}$ to allow for ANOVA. The means were compared by the Tukey ( $5 \%$ probability). The reduction in parasitism relative to the control treatment (distilled water) was computed by the equation: $\mathrm{E}(\%)=(1-\mathrm{Vt} / \mathrm{Vc}) \times 100$, in which $\mathrm{E}(\%)$ is the percent reduction in parasitism; $\mathrm{Vt}$ is the mean parasitism for the treatment tested; and $\mathrm{Vc}$ is the mean parasitism observed for the control treatment. The products were classified according to the IOBC standards, as follows: class 1, harmless $(\mathrm{E}<30 \%)$; class 2 , slightly harmful $(30 \% \leq \mathrm{E} \leq 79 \%)$; class 3, moderately harmful $(80 \% \leq \mathrm{E} \leq 99 \%)$; and class 4, harmful (E>99\%) (HASSAN, 1992).

\section{RESULTS}

Pupae trial: Even though there was differences among some treatments, it is important to emphasized that the tested organic supplies (treatments 1 to 8) did not reduce T. podisi emergence from treated pupae compared to control (distilled $\left.\mathrm{H}_{2} \mathrm{O}\right)(\mathrm{F}=14.3$; $\mathrm{df}_{\text {residue }}=40 ; \mathrm{P}<0.0001$ ) (Table 2) and were all classified as harmless (class 1) to this parasitoid stage, including the treatment with chlorpyrifos (Table 3). Chlorpyrifos $(384 \mathrm{~g})$, however, impact somehow the parasitism capacity of the parasitoid emerged from the sprayed pupae at the first $\left(\mathrm{F}=4.8 ; \mathrm{df}_{\text {residue }}=40 ; \mathrm{P}=0.0002\right)$ (Table 2) and the fifth $\left(\mathrm{F}=13.4 ; \mathrm{df}_{\text {residue }}=40 ; \mathrm{P}<0.0001\right)$ (Table 2) days after $F_{1}$ emergence and was classified as slightly harmful (class 2) (Table 3). None of the treatments impaired the emergence $(\%)$ of $\mathbf{T}$. podisi originating from the $F_{1}$ of adults emerged from treated pupae, including the positive control (chlorpyrifos $384 \mathrm{~g})$ neither at the first $\left(\mathrm{F}=1.78 ; \mathrm{df}_{\text {residue }}=40 ; \mathrm{P}=0.1024\right)$ nor at the fifth $\left(\mathrm{F}=1.1 ; \mathrm{df}_{\text {residue }}=40 ; \mathrm{P}=0.4164\right)$ days of parasitism (Table 2).

Adult trial: The results obtained for T. podisi adults were similar to those previously reported for pupae (Table 2). Only chlorpyrifos $384 \mathrm{~g}$ significantly reduced $\boldsymbol{T}$. podisi parasitism compared to the control treatment (distilled $\mathrm{H}_{2} \mathrm{O}$ ) after one day $\left(\mathrm{F}=17.8 ; \mathrm{df}_{\text {residue }}=40 ; \mathrm{p}<0.0001\right)$ and five days $\left(\mathrm{F}=15.1 ; \mathrm{df}_{\text {residue }}=40 ; \mathrm{P}<0.0001\right)$ after the parasitoids emerged and had contact with the dry residues of the treatments (Table 2). Therefore, chlorpyrifos 384g was slightly harmful (class 2) at the first day and moderately harmful (class 3) at the fifth day (Table 3) while the organic treatments were all harmless (class 1); except the derivatives from crustaceans at the fifthday evaluation which reduced parasitism in $43 \%$ and was slightly harmful (class 2) (Table 3).

\section{DISCUSSION}

This is the first report in literature regarding to the toxicity of the tested organic supplied on T. podisi pupae and adult. Overall, the present research has shown that the tested organic treatments are compatible for use in combination with the parasitoid preservation in organic pest management. Even chlorpyrifos was less noxious to T. podisi as compared to other egg parasitoids as Trichogramma pretiosum (BUENO et al., 2008) and T. cacoeciae (HASSAN et al., 1998), for example. It did not reduce adult emergence from sprayed pupae. Chlorpyrifos kill insects primarily by phosphorylation of the acetylcholinesterase enzyme (AChE) at the nerve endings. This type of 
Table 2 - Side-effects of organic agricultural supplies sprayed on the egg parasitoid Telenomus podisi.

\begin{tabular}{|c|c|c|c|c|c|}
\hline \multirow{2}{*}{$\begin{array}{l}\text { Treatment } \\
\left(\text { dosage } / 1801 \mathrm{H}_{2} \mathrm{O}\right)\end{array}$} & \multirow{2}{*}{$\begin{array}{c}\text { Sprayed pupae } \\
\text { Parasitoid } \\
\text { emergence }(\%)^{1,2}\end{array}$} & \multicolumn{2}{|c|}{----- 1 day after adult emergence ----- } & \multicolumn{2}{|c|}{------ 5 days after adult emergence ----- } \\
\hline & & $\begin{array}{c}\mathrm{F}_{1} \text { parasitism } \\
(\%)^{1,2}\end{array}$ & $\begin{array}{c}\mathrm{F}_{1} \text { parasitoid } \\
\text { emergence }(\%)^{1}\end{array}$ & $\mathrm{~F}_{1}$ parasitism $(\%)^{1}$ & $\begin{array}{c}\mathrm{F}_{1} \text { parasitoid } \\
\text { emergence }(\%)^{1}\end{array}$ \\
\hline \multicolumn{6}{|l|}{ Assay $1=$ pupae } \\
\hline 1) B. anticarsia $\left(140 \times 10^{9} \mathrm{cpi}\right)$ & $91.2 \pm 1.6 \mathrm{bc}$ & $68.1 \pm 6.8 \mathrm{ab}$ & $89.1 \pm 3.0^{\text {ns }}$ & $70.0 \pm 6.8 \mathrm{ab}$ & $87.4 \pm 4.9^{\text {ns }}$ \\
\hline 2) Bacillus thuringiensis (16.8g) & $80.8 \pm 2.8 \mathrm{cde}$ & $74.5 \pm 0.6 \mathrm{a}$ & $91.7 \pm 2.0$ & $81.5 \pm 3.8 \mathrm{a}$ & $82.4 \pm 4.2$ \\
\hline 3) Neem oil (9.6 ppm) & $92.0 \pm 2.5 \mathrm{bc}$ & $67.8 \pm 2.1 \mathrm{ab}$ & $92.9 \pm 1.5$ & $78.0 \pm 4.5 \mathrm{a}$ & $93.7 \pm 2.4$ \\
\hline 4) Deguelia utilis extract (4 1) & $74.9 \pm 2.3 \mathrm{e}$ & $73.6 \pm 3.0 \mathrm{a}$ & $92.9 \pm 1.7$ & $86.0 \pm 1.9 \mathrm{a}$ & $87.9 \pm 3.5$ \\
\hline $\begin{array}{l}\text { 5) Derivatives from crustaceans } \\
\text { (3L) }\end{array}$ & $89.3 \pm 3.0 \mathrm{bcd}$ & $71.7 \pm 3.8 \mathrm{a}$ & $92.1 \pm 2.1$ & $71.7 \pm 5.6 \mathrm{ab}$ & $88.3 \pm 2.8$ \\
\hline 6) Na silicate $2 \%(4 \mathrm{~L})$ & $99.1 \pm 0.4 \mathrm{a}$ & $71.9 \pm 3.8 \mathrm{a}$ & $82.7 \pm 5.3$ & $50.2 \pm 3.5 \mathrm{bc}$ & $93.3 \pm 4.0$ \\
\hline 7) Copper $7 \%$ + lime $3.3 \%(1.8 \mathrm{~L})$ & $95.9 \pm 1.0 \mathrm{ab}$ & $71.3 \pm 2.4 \mathrm{a}$ & $86.3 \pm 2.7$ & $41.9 \pm 4.5 \mathrm{~cd}$ & $82.7 \pm 8.0$ \\
\hline $\begin{array}{l}\text { 8) Sulfur } 20 \%+\text { quicklime } 10 \% \\
\text { (1.8L) }\end{array}$ & $97.2 \pm 1.2 \mathrm{ab}$ & $81.9 \pm 1.5 \mathrm{a}$ & $91.9 \pm 3.8$ & $66.9 \pm 7.4 \mathrm{ab}$ & $88.9 \pm 3.7$ \\
\hline 9) Chlorpyrifos (384g) & $83.6 \pm 3.1 \mathrm{cde}$ & $52.6 \pm 2.5 b$ & $82.7 \pm 3.3$ & $25.3 \pm 7.3 \mathrm{~d}$ & $97.8 \pm 1.2$ \\
\hline 10) Control $\left(\mathrm{H}_{2} \mathrm{O}\right)$ & $77.6 \pm 3.6 \mathrm{de}$ & $74.9 \pm 2.9 \mathrm{a}$ & $91.3 \pm 3.0$ & $66.2 \pm 4.1 \mathrm{abc}$ & $86.2 \pm 7.8$ \\
\hline $\mathrm{CV}(\%)$ & 7.08 & 8.28 & 7.57 & 18.28 & 11.89 \\
\hline \multicolumn{6}{|l|}{ Assay $2=$ adults } \\
\hline 1) B. anticarsia $\left(140 \times 10^{9} \mathrm{cpi}\right)$ & -3 & $67.2 \pm 3.1 \mathrm{ab}$ & $63.5 \pm 3.4^{\mathrm{ns}}$ & $46.9 \pm 7.1 \mathrm{ab}$ & $79.2 \pm 3.5 \mathrm{a}$ \\
\hline 2) Bacillus thuringiensis (16.8g) & - & $64.7 \pm 2.5 \mathrm{ab}$ & $66.8 \pm 4.8$ & $46.9 \pm 6.7 \mathrm{ab}$ & $80.2 \pm 2.0 \mathrm{a}$ \\
\hline 3) Neem oil (9.6ppm) & - & $73.2 \pm 4.1 \mathrm{ab}$ & $53.6 \pm 5.3$ & $41.7 \pm 2.2 \mathrm{abc}$ & $75.4 \pm 4.4 \mathrm{a}$ \\
\hline 4) Deguelia utilis extract (4L) & - & $69.7 \pm 3.2 \mathrm{ab}$ & $68.1 \pm 6.6$ & $46.7 \pm 2.1 \mathrm{ab}$ & $76.7 \pm 0.9 \mathrm{a}$ \\
\hline $\begin{array}{l}\text { 5) Derivatives from crustaceans } \\
\text { (3L) }\end{array}$ & - & $58.8 \pm 4.4 \mathrm{~b}$ & $79.0 \pm 7.7$ & $19.1 \pm 5.3 \mathrm{c}$ & $79.5 \pm 1.8 \mathrm{a}$ \\
\hline 6) Na silicate $2 \%(4 \mathrm{~L})$ & - & $71.9 \pm 4.2 \mathrm{ab}$ & $73.7 \pm 4.6$ & $65.8 \pm 9.1 \mathrm{a}$ & $79.1 \pm 3.3 \mathrm{a}$ \\
\hline 7) Copper $7 \%+$ lime $3.3 \%(1.8 \mathrm{~L})$ & - & $74.9 \pm 2.4 \mathrm{ab}$ & $69.1 \pm 6.5$ & $64.4 \pm 6.2 \mathrm{ab}$ & $77.1 \pm 5.6 \mathrm{a}$ \\
\hline $\begin{array}{l}\text { 8) Sulfur } 20 \%+\text { quicklime } 10 \% \\
\text { (1.8L) }\end{array}$ & - & $79.6 \pm 5.2 \mathrm{a}$ & $72.3 \pm 3.9$ & $46.7 \pm 6.6 \mathrm{ab}$ & $89.9 \pm 4.2 \mathrm{a}$ \\
\hline 9) Chlorpyrifos (384g) & - & $23.6 \pm 0.5 \mathrm{c}$ & $58.1 \pm 4.6$ & $0.5 \pm 0.5 \mathrm{~d}$ & $0.0 \pm 0.0 \mathrm{~b}$ \\
\hline 10) Control $\left(\mathrm{H}_{2} \mathrm{O}\right)$ & - & $75.4 \pm 5.6 \mathrm{ab}$ & $66.1 \pm 5.0$ & $33.5 \pm 7.7 \mathrm{bc}$ & $72.8 \pm 2.5 \mathrm{a}$ \\
\hline CV $(\%)$ & - & 12.88 & 17.94 & 23.44 & 10.09 \\
\hline
\end{tabular}

${ }^{1}$ Means \pm SE followed by the same letter in each assay column are not statistically different by Tukey test $(\mathrm{P}>0.05) ;{ }^{2}$ Original data followed by statistics performed on data transformed into arcsin $\sqrt{X / 100}$ to allow for ANOVA according to BURR \& FOSTER (1972); ${ }^{3}$ Nonexisting parameter; ${ }^{\text {ns }}$ ANOVA non-significant.

poisoning causes loss of the available AChE and over-stimulation of organs by excess of acetylcholine at the nerve endings, and affects beneficial and pest insects similarly (CARMO et al., 2010). Therefore, even though organophosphates are generally harmful to all insect groups this research showed that there are differences among different insect species. The high T. podisi pupae tolerance to the pesticide is probably due to the protection provided by the host egg. That is the reason the pupal phase of egg parasitoids is admittedly the most tolerant phase to pesticides (CARMO et al., 2010). Furthermore, the difference between Trichogramma spp. and $\mathbf{T}$. podisi may be a result from the relatively thicker egg of $\boldsymbol{E}$. heros, the host of $\mathbf{T}$. podisi, which may provide better mechanical protection from the treatments than the thinner eggs of A. kuehniella, the host of Trichogramma.

Because the organophosphates are among the least expensive insect-control products available to conventional soybean growers, they are often overused (BUENO et al., 2011). Their application, however, is not compatible with egg parasitoids, as shown in this study. Thus, the use of organophosphates, whenever possible, could be replaced by other products more compatible with biological control preservation. Despite this, reactive approaches have continued to dominate pest management decision-making because the costs of pesticides are comparatively low. However, the price of the pesticide does not reflect the risks and social costs associated with their use (YERGAN, 
Table 3 - Placement of organic supplies sprayed on the egg parasitoid Telenomus podisi into IOBC survival side-effect classes.

\begin{tabular}{|c|c|c|c|c|c|c|c|c|c|c|}
\hline \multirow{3}{*}{ Treatment (dosage/180 $\mathrm{L} \mathrm{H}_{2} \mathrm{O}$ ) } & \multicolumn{6}{|c|}{--------------------------- Pupae bioassay -------------------------- } & \multicolumn{4}{|c|}{---------- Adult bioassay ---------- } \\
\hline & \multicolumn{2}{|c|}{----- Pupae ----- } & \multicolumn{2}{|c|}{$\begin{array}{c}1 \text { day after } F_{1} \\
\text { parasitoid } \\
\text { emergence }\end{array}$} & \multicolumn{2}{|c|}{$\begin{array}{c}5 \text { days after } \mathrm{F}_{1} \\
\text { parasitoid } \\
\text { emergence }\end{array}$} & \multicolumn{2}{|c|}{$\begin{array}{c}1 \text { day after } F_{1} \\
\text { parasitoid } \\
\text { emergence }\end{array}$} & \multicolumn{2}{|c|}{$\begin{array}{c}5 \text { days after } F_{1} \\
\text { parasitoid } \\
\text { emergence }\end{array}$} \\
\hline & $\mathrm{E} \%{ }^{1}$ & $\mathrm{C}^{2}$ & $\mathrm{E} \%{ }^{1}$ & $\mathrm{C}^{2}$ & $\mathrm{E} \%{ }^{1}$ & $\mathrm{C}^{2}$ & $\mathrm{E} \%{ }^{1}$ & $\mathrm{C}^{2}$ & $\mathrm{E} \%{ }^{1}$ & $\mathrm{C}^{2}$ \\
\hline B. anticarsia (140 x $\left.10^{9} \mathrm{cpi}\right)$ & 0.0 & 1 & 9.1 & 1 & 0.0 & 1 & 10.9 & 1 & 0.0 & 1 \\
\hline Bacillus thuringiensis (16.8g) & 0.0 & 1 & 0.6 & 1 & 0.0 & 1 & 14.2 & 1 & 0.0 & 1 \\
\hline Neem oil (9.6ppm) & 0.0 & 1 & 9.5 & 1 & 0.0 & 1 & 3.0 & 1 & 0.0 & 1 \\
\hline Deguelia utilis extract (4L) & 3.5 & 1 & 1.8 & 1 & 0.0 & 1 & 7.6 & 1 & 0.0 & 1 \\
\hline Derivatives from crustaceans (3L) & 0.0 & 1 & 4.4 & 1 & 0.0 & 1 & 22.1 & 1 & 43.1 & 2 \\
\hline Na silicate $2 \%(4 \mathrm{~L})$ & 0.0 & 1 & 4.1 & 1 & 24.2 & 1 & 4.7 & 1 & 0.0 & 1 \\
\hline Copper $7 \%+$ lime $3.3 \%(1.8 \mathrm{~L})$ & 0.0 & 1 & 4.9 & 1 & 36.7 & 2 & 0.7 & 1 & 0.0 & 1 \\
\hline Sulfur $20 \%+$ quicklime $10 \%(1.8 \mathrm{~L})$ & 0.0 & 1 & 0.0 & 1 & 0.0 & 1 & 0.0 & 1 & 0.0 & 1 \\
\hline Chlorpyrifos (38 g) & 0.0 & 1 & 30.0 & 2 & 61.8 & 2 & 68.7 & 2 & 98.5 & 3 \\
\hline
\end{tabular}

${ }^{1} \mathrm{E}(\%)=(1-\mathrm{Vt} / \mathrm{Vc}) \times 100$, in which $\mathrm{E}(\%)$ is the percent reduction in parasitism or parasitoid emergence; Vt is the median parasitism for the treatment tested; and $\mathrm{Vc}$ is the average parasitism observed for the control treatment $(\mathrm{HASSAN}, 1992) .{ }^{2} \mathrm{Classes}: 1=$ harmless $(\mathrm{E}<30 \%), 2=$ slightly harmful $(30 \leq \mathrm{E} \leq 79 \%), 3=$ moderately harmful $(80 \leq \mathrm{E} \leq 99 \%), 4=$ harmful $(\mathrm{E}>99 \%)$.

1982); if these are taken into account, the benefits of organic farming are more apparent.

The nutritional quality and the safety of organic food has been well documented (LAIRON, 2010) and this present study helps to understand its safety for natural biological control agents as well. A reduction in the parasitism rate, as an effect from the application of products in organic agriculture, only occurred at the last day of evaluation. Importantly, $\boldsymbol{T}$. podisi showed greater parasitism in the first days of life (YERGAN, 1982). This may occur because the reproductive capacity of the parasitoids diminishes with age, besides other biotic and abiotic factors that may influence their behavior (NAKAMA \& FOERSTER, 2001).

The baculovirus anticarsia has been reported to be harmless to natural enemies, as demonstrated in this study for the egg parasitoid T. podisi. Besides baculovirus anticarsia selectivity, T. podisi were also not impacted by the action of Bacillus thuringiensis, which is another important bioinsecticide used in organic agriculture for the control of lepidopterans. Similarly, $\boldsymbol{B}$. thuringiensis has been reported to be compatible with other species of biological-control agents, for example Trichogramma dendrolimi (TAKADA et al., 2001). This compatibility may result from the need for the bacterium to be ingested to have an effect, and therefore contact via tegument, as analyzed in this experiment, was not able to contaminate the parasitoids.

One commonly used botanical pest repellent and insecticide is neem oil (Azadirachta indica). Neem extracts produce multiple effects on insects, including repellency, reduced feeding, decreased oviposition, interruption of development and ecdysis, reduced fertility and fecundity, behavioral alterations, developmental delay, and mortality (MORDUE et al., 2000). Plant extracts such as neem are reported to be non-selective to natural enemies. After spraying neem oil on eggs of the host A. kuehniella, it was observed a reduction in the parasitism of T. pretiosum (GONÇALVES-GERVÁSIO \& VENDRAMIM, 2004). The product Neemseto ${ }^{\circledR}$ used in the present experiment, however, did not reduce parasitism compared to the control treatment for T. podisi in the first 24 hours. After that period, Neemseto ${ }^{\circledR}$ was slightly harmful (class 2) to T. podisi. These differences in results may be due to differences in the concentration of the products used or to methodological differences among the experiments. Many neem-based products are not standardized for the concentration of the active ingredient, and for this reason, differences in selectivity as well as in the efficiency of commercial formulations may exist and should be evaluated before they are used under field conditions.

The tested product Arrast $^{\circledR}$ is formulated with an extract of the plant Deguelia utilis (Leguminosae: Papilionoideae) containing rotenone. Rotenone is reported to cause inhibition of the mitochondrial respiratory chain, reducing oxygen consumption (MASCARO et al., 1998) and the production of ATP (adenosine triphosphate, $\mathrm{C}_{10} \mathrm{H}_{16} \mathrm{~N}_{5} \mathrm{O}_{13} \mathrm{P}_{3}$ ), which is necessary for the metabolism and development of insects. It was observed that different concentrations of Rotenat $^{\circledR}$, formulated 
from the extract of the plant Ateleia glazioviana (Leguminosae: Papilionoideae) significantly affected adult of the fruit fly Anastrepha fraterculus (Diptera: Tephritidae) (EFROM et al., 2011). Arrast ${ }^{\circledR}$, however, was selective for the egg parasitoid evaluated here, thus showing that it is compatible with the preservation of these important biological control agent.

Besides the side-effects of insecticides, it is also important to study the possible side effects of fungicides and herbicides, which are sometimes assumed to be harmless to beneficial arthropods, although this cannot be taken for granted (BUENO et al., 2008). Fishfértil Indure ${ }^{\circledR}$ is an organic fertilizer (nitrogen + phosphorus + carbon) derived from natural enzymatic fermentation of marine fish, enriched with chitosan from shells of crustaceans, and used for foliar application. This product, which contains a biologically active amino-acid complex, is reputed to act as a natural regulator of the nutritional balance of plants, promoting increased photosynthesis. The chitosan present in Fishfértil Indure ${ }^{\circledR}$ is claimed by the manufacturers to induce the plants' genes for resistance to pests and diseases by augmenting their natural defense system. Despite of its possible effects on insects, this treatment was harmless to pupae of T. podisi. Regarding to adults, this treatment was also harmless at 1 day after $F_{1}$ parasitoid emergence but it was classified as slightly harmful (class 2) at 5 days after F1 parasitoid emergence. Similarly to the treatment with Fishfértil Indure ${ }^{\circledR}$, the treatment with $2 \%$ sodium silicate was selective for the egg parasitoids evaluated, and thus the use of both products is compatible with the parasitoid.

The use of bio-protective mixtures such as Bordeaux mixture and lime-sulfur mixture has increased in recent years, and has proved to be efficient in controlling several different pests (GONÇALVES et al., 2004). However, few studies have evaluated their effect on beneficial arthropods (EFROM et al., 2011). Experiments carried out under field conditions revealed the toxicity of sulfur to some predators (TEODORO et al., 2005). The results obtained here, however, did not indicate negative effects of the sulfur + lime mixture for T. podisi in $\boldsymbol{E}$. heros eggs. The mechanisms of action of these products on the insects are not well known, but in the case of the lime-sulfur mixture, sulfur, its main component, can inhibit cellular respiration (IRAC, 2009).

\section{CONCLUSION}

The tested organic supplies, baculovirus anticarsia $140 \times 10^{9}$ cpi; Bacillus thuringiensis
$16.8 \mathrm{~g}$; azadirachtin-A, azadirachtin-B, nimbina and salamina 9.6 ppm; rotenoids 4 liters; nitrogen 1.3\%, phosphorus $3.0 \%$ and total organic carbon $8.0 \%$ 3 liters; sodium silicate 2\% 4 liters; copper $7 \%+$ calcium 3.3\% 1.8 liters and; sulfur 20\% + quicklime $10 \% 1.8$ liters are harmless to pupae and adults of T. podisi. Differently, chlorpyrifos $384 \mathrm{~g}$ has some negative impact on $\boldsymbol{T}$. podisi.

\section{REFERENCES}

BUENO, A.F. et al. Effects of pesticides used in soybean crops to the egg parasitoid Trichogramma pretiosum. Ciência Rural, v.38, n.6, p.1495-1503, 2008. Available from: <http://www.scielo. br/scielo.php?pid $=$ S0103-84782008000600001\&script $=$ sci abstract $>$. Accessed: June, 12. 2012. doi: 10.1590/S010384782008000600001 .

BUENO, A.F. et al. Effects of integrated pest management, biological control and prophylactic use of insecticides on the management and sustainability of soybean. CropProtection, v.30,n.7,p.937-945, 2011. Available from: <http://ac.els-cdn.com/S0261219411000640/1s 2.0-S0261219411000640-main.pdf?_tid=5c06687a550 e-11e2-b475-00000aab0f26\&acdnat $=1357153273$ ae4eab2b9412ed7be17d634b31ba424b>. Accessed: Jul. 12, 2012. doi: 10.1016/j.cropro.2011.02.021.

BURR, I.W.; FOSTER. L.A. A test for equality of variances. West Lafayette: University of Purdue, 1972. 26p.

CARMO, E.L. et al. Pesticide selectivity for the insect egg parasitoid Telenomus remus. BioControl, v.55, p.455-464, 2010. Available from: <http://ainfo.cnptia.embrapa.br/digital/bitstream/ item/35526/1/fulltext3.pdf $>$. Accessed: Jul. 9, 2012. doi: 10.1007/ s10526-010-9269-y.

EFROM, C.F.S. et al. Laboratory evaluation of phytosanitary products used for control of the South American fruit fly, Anastrepha fraterculus, in organic farming. Crop Protection, v.30, n.7, p.1162-1167, 2011. Available from: <http://ac.els-cdn. com/S0261219411001712/1-s2.0-S0261219411001712-main. pdf?_tid=6ae2d0c4-5598-11e2-a8ee-00000aacb362\&acdnat $=135$ 7212569_9c23b095f8093a481444479f6c7e819c>. Accessed: Jul. 10, 2012. doi: 10.1016/j.cropro.2011.05.007.

FOERSTER, L.A. et al. Emergence, longevity and fecundity of Trissolcus basalis and Telenomus podisi after cold storage in the pupal stage. Pesquisa Agropecuária Brasileira, v.39, n.9, p.841-845, 2004. Available from: <http://www.scielo.br/pdf/ pab/v39n9/22026.pdf $>$. Accessed: Sept. 10, 2012. doi: 10.1590/ S0100-204X2004000900002.

GONÇALVES-GERVÁSIO, R.C.R.; VENDRAMIM, J.D. Efeito de extratos de Meliáceas sobre o parasitóide de ovos Trichogramma pretiosum Riley (Hymenoptera: Trichogrammatidae). Neotropical Entomology, v.33, n.5, p.607-612, 2004. Available from: <http://www.scielo.br/pdf/ne/v33n5/22683.pdf >. Accessed: Sept. 10, 2012. doi: 10.1590/S1519-566X2004000500010.

GONÇALVES, P.A.S. et al. Avaliação de biofertilizantes, extratos vegetais e diferentes substâncias alternativas no manejo de tripes em cebola em sistema orgânico. Horticultura Brasileira, v.22, n.3, p.659-662, 2004. 
HASSAN, S.A. et al. The side-effects of pesticides on the egg parasitoid Trichogramma cacoeciae Marchal (Hymenoptera: Trichogrammatidae), acute dose-response and persistence tests. Journal of Applied Entomology, v.122, n.9-10, p.569573, 1998. Available from: <http://onlinelibrary.wiley.com/ doi/10.1111/j.1439-0418.1998.tb01547.x/pdf>. Accessed: Jul. 10, 2012. doi: 10.1111/j.1439-0418.1998.tb01547.x.

HASSAN, S.A. Guideline for the evaluation of side-effects of plant protection product on Trichogramma cacoeciae. In: HASSAN, S.A. (Ed.). Guidelines for testing the effects of pesticides on beneficial organisms: description of test methods. IOBC/WPRS Bulletin, v.15, p.18-39, 1992.

IRAC (INSECTICIDE RESISTANCE ACTION COMMITTEE). Advances in the implementation of pesticide resistance management programs in Brazil, 2009. Available from: $<\mathrm{http}: / /$ www.irac-br.org.br/biblio.htm>. Accessed: Feb. 14, 2012.

LAIRON, D. Nutrional quality and safety of organic food. A review. Agronomy Sustainable Development, v.30, n.1, p.3341, 2010. Available from: <http://www.agronomy-journal.org/ index.php?option $=$ com_article $\&$ access $=$ doi $\&$ doi $=10.1051 /$ agro/2009019\&Itemid $=129>$. Accessed: Feb. 9, 2012. doi: 10.1051/agro/2009019.

MASCARO, U.C.P. et al. Valores de $\mathrm{DL}_{50}$ em peixes e no rato tratados com pó de raízes de Derris spp e suas implicações ecotoxicológicas. Pesquisa Veterinária Brasileira, v.18, n.2, p.53-56, 1998. Available from: <http://www.scielo.br/pdf/pvb/ v18n2/0893.pdf>. Accessed: Jul. 16, 2012. doi: 10.1590/S0100$736 \times 1998000200002$.

MCBRIDE, W.D.; GREENE, C. The profitability of organic soybean production. Renewable Agriculture Food System, v.24, n.4, p.276-284, 2009. Available from: <http://journals.cambridge. org/action $/$ displayAbstract? fromPage $=$ online $\&$ aid $=6642460>$. Accessed: Jul. 16, 2012. doi: 10.1017/S1742170509990147.

MORDUE (LUNTZ), A.J.; NISBET, A.J. Azadirachtin from the neem tree Azadirachta indica: its action against insects. Anais da Sociedade Entomológica do Brasil, v.29, n.4, p.615632, 2000. Available from: <http://www.scielo.br/scielo. php?script $=$ sci_arttext $\&$ pid $=$ S0301-80592000000400001\&lng $=$ e n\&nrm=iso\&tlng=en $>$. Accessed: Sept. 03, 2012. doi: 10.1590/ S0301-80592000000400001.

NAKAMA, P.A.; FOERSTER, L.A. Efeito da alternância de temperaturas no desenvolvimento e emergência de Trissolcus basalis (Wollaston) e Telenomus podisi Ashmead (Hymenoptera:
Scelionidae). Neotropical Entomology, v.30, n.2, p.269-275, 2001. Available from: <http://www.scielo.br/pdf/ne/v30n2/a10v30n2.pdf>. Accessed: Sept. 10, 2012.

OERKE, E.C. Crop losses to pests. Journal of Agricultural Science and Technology, v.144, p.31-43, 2006.

PANIZZI, A.R.; OLIVEIRA, E.D.M. Performance and seasonal abundance of the Neotropical brown stink bug, Euschistus heros nymphs and adults on a novel food plant (pigeon pea) and soybean. Entomologia Experimentalis et Applicata, v.88, n.2, p.169-175, 1998. Available from: <http://onlinelibrary.wiley. com/doi/10.1046/j.1570-7458.1998.00359.x/pdf>. Accessed: Jul. 2012. doi: 10.1046/j.1570-7458.1998.00359.x.

SHAPIRO, S.S.; WILK, M.B. An analysis of variance test for normality. Biometrika, v.52, p.591-611, 1965.

TAKADA, Y. et al. Effects of various insecticides on the development of the egg parasitoid Trichogramma dendrolimi (Hymenoptera: Trichogrammatidae). Journal of Economic Entomology, v.94, n.6, p.1340-1343, 2001. Available from: $<$ http://www.bioone.org/doi/pdf/10.1603/0022-0493-94.6.1340>. Accessed: Sept. 20, 2012. doi: 10.1603/0022-0493-94.6.1340.

TEODORO, A.V. et al. Lethal and sub-lethal selectivity of fenbutatin oxide and sulfur to the predator Iphiseiodes zuluagai (Acari: Phytoseiidae) and its prey, Oligonychus ilicis (Acari: Tetranychidae), in Brazilian coffee plantations. Experimental \& Applied Acarology, v.36, n.1-2, p.61-70, 2005. Available from: <http://link.springer.com/content/pdf /10.1007\%2Fs10493-005-0507-4>. Accessed: Jul. 10, 2012. doi: 10.1007/s10493-005-0507-4.

WILLER, H.; KILCHER, L. The world of organic agriculture: statistics and emerging trends 2009. IFOAM, Bonn, FiBL, Frick and ITC, 2009. 304p. (IFOAM FiBL Report). Available from: $<$ http:// orgprints.org/18380/16/willer-kilcher-2009.pdf>. Accessed: Feb. $10,2012$.

YERGAN K.V. Reproductive capability and longevity of the parasitic wasps Telenomus podisi and Trissolcus euschisti. Annals of the Entomological Society of America, v.75, n.2, p.181-183, 1982 .

ZEHNDER, G. et al. Arthopod pest management in organic crops. Annual Review of Entomology, v.52, p.57-80, 2007. Available from: <http://www.annualreviews.org/doi/full/10.1146/ annurev.ento.52.110405.091337?url ver=Z39.88-2003\&rfr $\mathrm{id}=$ ori:rid:crossref.org\&rfr_dat $=$ cr_pub $=$ pubmed $\&>$. Accessed: Jun. 11, 2012. 